\title{
DESCRIPTIONS OF TWO NEW SPECIES OF ENCYRTIDAE (HYMENOPTERA: CHALCIDOIDEA) FROM WEST BENGAL, INDIA
}

\author{
Mohammad Hayat \\ Department of Zoology, Aligarh Muslim University, Aligarh, Uttar Pradesh 202002, India. \\ Email:mohd_hayat@rediffmail.com
}

\begin{abstract}
Two new species of Encyrtidae, one each belonging to Psyllaephagus Ashmead and Copidosoma Ratzeburg, are described. The material of these species was reared from hosts collected in Balurghat, in the Indian State of West Bengal.
\end{abstract}

Keywords

Copidosoma, Encyrtidae, Hymenoptera, new species, Psyllaephagus

\section{Introduction}

This paper deals with two encyrtid species collected from West Bengal, India and sent to me by Prof. T.C. Narendran. The genus Psyllaephagus Ashmead is cosmopolitan in distribution, containing about 160 species. From India, however only eight species are described. These are: aizawlensis Singh, 1996; aligarhensis Shafee, Alam and Agarwal, 1975; macrohomotoma Singh and Agarwal, 1993; mesohomotoma Singh and Agarwal, 1993; mycopsyllus Singh, 1996; phylloplectae Sushil and Khan, 1995; Solanensis Sushil and Khan, 1995; tekeddyensis Singh and Agarwal, 1993.

The genus Copidosoma Ratzeburg contains 212 species distributed worldwide. The Indian species have recently been revised by Kazmi and Hayat (1998). They recognized a total of 26 species (including two introduced species) from India, and provided a key for the separation of these species.

\section{Psyllaephagus bengalensis sp. nov.}

(Figs. 1-6)

\section{Material examined}

Holotype: Female, 4.iii.2000, Balurghat, West Bengal, India, ex indet. Psyllids on Syzygium cumini, coll. B.K. Das, N.P.C., I.A.R.I., New Delhi

Paratypes: Three females (one female on slide, No. EH.1074), 4.iii.2000, Balurghat, West Bengal, India, ex indet. Psyllids on
Syzygium cumini, coll. B.K. Das, Hayat collection, Aligarh.

\author{
Host \\ Psyllids (Homoptera: Psylloidea) on Syzygium cumini (L.)
}

\section{Distribution}

India: Balurghat in West Bengal

\section{Etymology}

The specific name is derived from the name of the Indian state from where the specimens were collected.

\section{Diagnostic features}

Female: Length $1.09 \mathrm{~mm}$. Body dark brown to black, shiny, metallic dull bronzy purple; mesoscutum largely matt (the area with lineolate-reticulate sculpture), with reticulate medioposterior part faint purple to bronzy; scutellum largely violetbronzy, smooth margins faint blue-green and violet; tegulae dark brown. Antenna with radicle, basal two-thirds of scape, dorsal surface in proximal two-thirds of pedicel, dark brown; rest of antennal segments yellow. Wings hyaline. Legs, including fore coxae, white to pale yellow; mid and hind coxae, hind femur and hind tibia in about proximal third, dark brown; mid femur with a brownish patch at apex, and mid tibia with faint brownish at base.

Head with frontovertex width less than one-third of head width; ocellar triangle with apical angle slightly acute; posterior occlli about half their diameter to eye margins, and about two diameters 


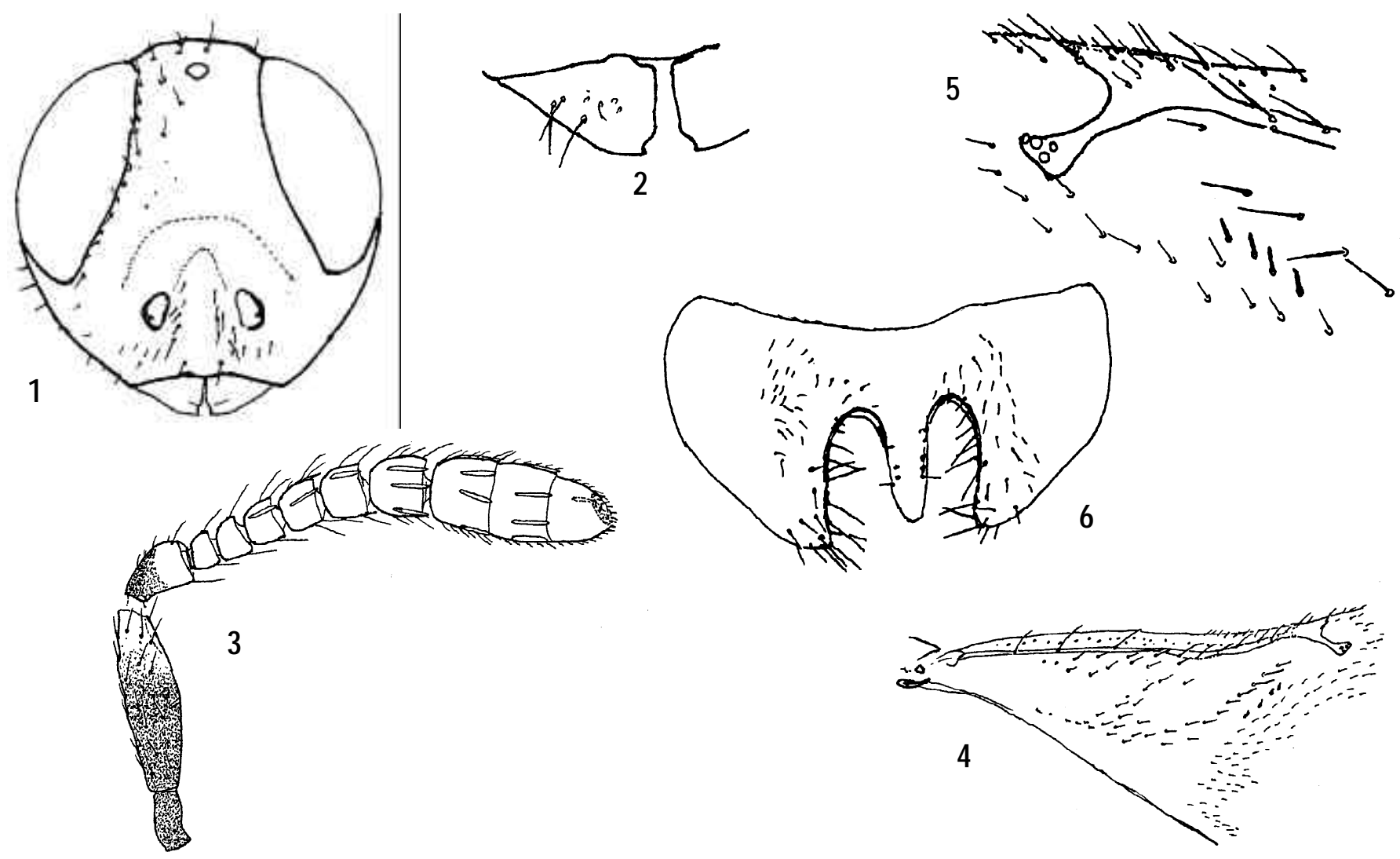

Figures 1-6. Psyllaephagus bengalensis sp. nov. (female)

1 - Head, frontal; 2 - Mandibles; 3 - Antenna; 4 - Fore wing basal part; 5 - Distal veins of fore wing; 6 - Hypopygium

to occipital margin, frontovertex with regular, polygonally reticulate sculpture, and with minute setigerous punctures, malar space with sculpture fine, largely elongate-reticulate, other details as in Fig. 1. Mandible (Fig. 2) with a small tooth and a broad truncation. Antenna as in Fig. 3; pedicel longer than first two funicle segments combined; funicle segments broader than long to at most quadrate. Relative measurements (from holotype): Head dorsal width, 34; frontovertex width, 10.5; distance between posterior ocelli, six; distance from a posterior ocellus to anterior ocellus, five. Scape length, 9.5; flagellum length, 23.

Thorax: Mesoscutum sparsely setose, with lineolate-reticulate sculpture, in posterior half of median area and along posterior margin where the sculpture is polygonally reticulate; axillae with sculpture fine, but transversely lineolate reticulate; scutellum with longitudinally elongate to lineolate-reticulate sculpture, except medially where the cells are polygonal; scutellum with three pairs of setae; propodeum on each side just distad of spiracles, with a longitudinal anteromesally curved ridge. Fore wing venation and basal setation as in Figs. 4 and 5. Relative measurements (from holotype): Thorax length, 39; pronotum width, 30; mesoscutum length (width), 17 (33); scutellum length (width) 17 (20) (from slide; paratype); fore wing length (width), 134 (56); hind wing length (width), 89 (23).

Gaster shorter than thorax (29:39), terga with very fine, transversely lineolate-reticulate sculpture; hypopygium (Fig. 6) with trilobed posterior margin. Relative measurements (from slide; paratype): last tergite length, 30; ovipositor length, 40; third valvula length, seven (mid tibia length, 57; mid basitarsus length, 14; mid tibial spur length, 13).

Male: Unknown.

\section{Remarks}

This new species differs from all the known Indian species of Psyllaephagus, by the short funicle segments, longitudinally elongate to lineolate-reticulate sculpture of the mesoscutum and scutellum, and the distinctly trilobed hypopygium. In the 

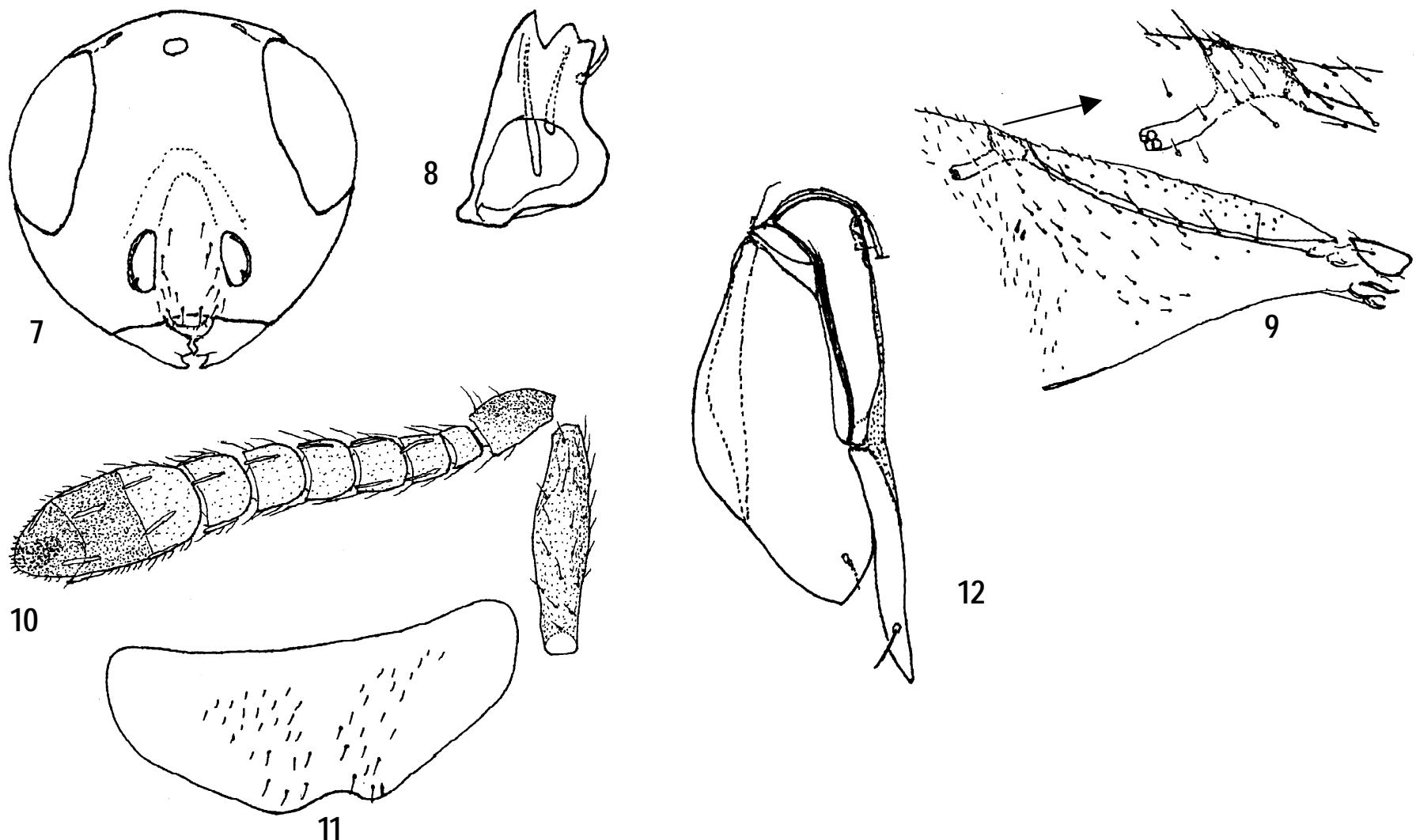

Figures 7-12. Copidosoma dasi sp. nov. (female)

7 - Head, frontal; 8 - Mandible; 9 - Fore wing showing venation and setation, with distal veins enlarged; 10 - Antenna; 11 - Hypopygium; 12 - Ovipositor, right half

key to the Southern African species given by Prinsloo (1981), the new species runs to africanus (there as argutus, a preoccupied name, and replaced by africanus by Prinsloo, 1985), but differs as follows: head metallic dull purple bronzy; mesoscutum largely matt; tegulae completely dark brown; mid femur with a brown patch at apex; head about $3 \mathrm{x}$ of frontovertex width; funicle with first segment smallest, but segments gradually increasing in width and length distally; mesoscutum and scutellum largely with elongate-reticulate to lineolatereticulate sculpture; scutellum with three pairs of setae; ovipositor clearly shorter than mid tibia (40:57). Third valvula slightly more than half of mid tibial spur (7:13); hypopygium with apex trilobed [in africanus: head and thoracic dorsum metallic green; tegulae, except blackish distal ends, sordid white. mid femur completely white; head about $2 \mathrm{x}$ of fronto-vertex width; antenna with basal two funicle segments smaller than each of the following segments, mesonotal sculpture raised reticulate; scutellum with 25-30 setae; ovipositor a little longer than mid tibia (about 1.2:1); third valvula about as long as mid tibial spur. Shape of hypopygium is unknown in this species].

\section{Copidosoma dasi sp. nov.}

(Figs. 7-12)

\section{Material examined}

Holotype: Female, 25.iii.2000, Balurghat, West Bengal, India, ex indet. lepidopteran gall maker on Syzygium cumini, coll. B.K. Das, N.P.C., I.A.R.I., New Delhi.

Paratypes: 26 females (three females on slides, EH. 1075, EH. 1078, EH. 1079), 25.iii.2000, Balurghat, West Bengal, India, ex indet. lepidopteran gall maker on Syzygium cumini, coll. B.K. Das. Two female paratypes in N.P.C., I.A.R.I., New Delhi, rest in Hayat collection, Aligarh.

Additional specimens examined, but not designated as types: 32 females (in alcohol in a vial), with data same as for holotype.

\section{Host}

Gall making Lepidoptera on Syzygium cumini (L.)

\section{Distribution}

India: Balurghat in West Bengal. 


\section{Etymology}

This species is named in honour of Dr. B.K. Das, who collected the specimens.

\section{Diagnostic features}

Female: Length, $1.04 \mathrm{~mm}$. Body completely dark brown, metallic; head bluish-green; sides of scrobes and scrobes bronzy; pronotal collar bronzy-violet; mesoscutum mainly bluish-green, with bronzy on sides and along posterior margin; axillae and scutellum bronzy-violet; tegulae dark brown; mesopleura bluishgreen in anterior half, bronzy-violet in posterior half; metanotum, propodeum and gaster mainly blackish, with bronzy-violet on gaster. Antenna with radicle and proximal two-thirds of pedicel brown; scape, rest of pedicel, and flagellum mainly yellow brown, with brownish suffusions on scape and distal two claval segments. Wings hyaline. Legs with all coxae dark brown, bronzy-violet; fore femur and tibia, except both ends, brownish; mid femur pale brownish except distal end; hind femur except both ends, and hind tibia except base and distal half, brownish.

Head width about twice of frontovertex width; fronto-vertex with regular reticulate sculpture; ocellar triangle with apical angle slightly obtuse; ocello-occipital margin distance about twice of ocello-ocular distance; otherwise as in Fig. 7. Mandible (Fig. 8) tridentate, inner tooth distinct. Antenna as in Fig. 10; first funicle segment shorter and narrower than second segment; all funicle segments quadrate $(2-5)$ to broader than long $(1,6)$; clava three-segmented, third segment with a small, oblique truncation. Relative measurements (from holotype): Head dorsal width, 32; fronto-vertex width, 15; head frontal length, 29; eye length, 17; malar space length, 11; distance between posterior ocelli, 10; distance of a posterior ocellus to eye margin, 1.5; distance of a posterior ocellus to occipital margin, 3 ; distance of a posterior ocellus to anterior ocellus, 4. Antennal scape length, 12. flagellum length, 25 .

Thorax: Mesoscutum, axillae and scutellum with regular, polygonally reticulate sculpture, the cells larger; sculpture of scutellum less prominent than of mesoscutum. Fore wing venation and setation as in Fig. 9. Relative measurements (from holotype): Thorax length, 38; mesoscutum length (width), 18 (30); scutellum length (width), 17 (17) (from slide, paratype): fore wing length (width), 124 (53); venation length, 55; hind wing length (width), 84 (24); venation length, 55.

Gaster shorter than thorax (27:38); ovipositor as in Fig. 12; hypopygium as in Fig 11. Relative measurements (from slide, paratype): ovipositor length, 36; third valvula length, 17. [Mid tibia length, 50; mid basitarsus length, 15; mid tibial spur length, $10.5]$.

Male: Unknown.

\begin{abstract}
Remarks
Copidosoma dasi sp. nov. does not agree with any of the 26 Indian species (Kazmi \& Hayat, 1998) or the Palaearctic species (Trjapitzin, 1989) in the following combination of characters: short and transverse first funicle segment; quadrate to broader than long funicle segments; three-segmented clava of which the third segment has a short, oblique truncation; almost punctiform marginal vein and very short postmarginal vein; mesoscutum and scutellum with fine, wide-meshed, polygonally reticulate sculpture; unexserted ovipositor, and the shape of the hypopygium.
\end{abstract}

\section{Acknowledgements}

I thank Dr. B.K. Das, Department of Agricultural Entomology, Bidhan Chander Krishividyalaya, Mohanpur, Nadia, West Bengal for collecting the specimens, and Prof. T.C. Narendran, Department of Zoology, University of Calicut for passing these specimens on to me for study.

\section{References}

Kazmi, S.I. and M. Hayat (1998). Revision of the Indian Copidosomatini (Hymenoptera: Chalcidoidea: Encyrtidae). Oriental Insects 32: 287-362.

Prinsloo, G.L. (1981). On the encyrtid parasites (Hymenoptera: Chalcidoidea) associated with psyllids (Hemiptera: Psylloidea) in Southern Africa. Journal of the Entomological Society of Southern Africa 44: 199-244.

Prinsloo, G.L. (1985). Afrotropical Encyrtidae (Hymenoptera: Chalcidoidea), new records and notes. Journal of Natural History 19: 277-284.

Shafee, S.A., S.M. Alam and M.M. Agarwal (1975). Taxonomic survey of encytrid parasites (Hymenoptera: Encyrtidae) in India. Aligarh Muslim University Publications (Zoological Series) on Indian Insect Types 10: iii+125pp.

Singh, S. (1996). Two new species of Psyllaephagus Ashmead (Hymenoptera: Chalcidoidea: Encyrtidae) attacking Mycopsylla sp. (Homoptera: Psyllidae) infesting Ficus religiosa in Mizoram, India. Oriental Insects 30: 155-166.

Singh, S. and M.M. Agarwal (1993). Taxonomic studies on Indian encyrtid parasites (Hymenoptera: Encyrtidae) from northeastern region. Aligarh Muslim University Zoological Publications, Indian Insect Types 14: 180.

Sushil, S.N. and M.A. Khan (1995). Two new species of Psyllaephagus (Hymenoptera: Encyrtidae) from northern India. Journal of Insect Science 8: 20-23.

Trjapitzin, V.A. (1989). Parasitic Hymenoptera of the fam. Encyrtidae of the Palaearctics. (In Russian). Opredeliteli po faune SSSR lzdavavaemiye Zoologica In: Tom AN SSSR 158, Leningrad, Nauk, 487pp. 